\title{
Biochemical characterization of a family IV esterase with $R$-form enantioselectivity from a compost metagenomic library
}

\author{
Jong Eun Park, Geum Seok Jeong, Hyun Woo Lee and Hoon Kim ${ }^{*}$ (1)
}

\begin{abstract}
A novel family IV esterase (hormone-sensitive lipase, HSL) gene, est15L, was isolated from a compost metagenomic library. Encoded Est15L comprised 328 amino acids with a molecular weight of 34,770 kDa and was an intracellular esterase without a signal peptide. The multiple sequence alignment (MSA) of Est15L with other family IV esterases showed conserved regions such as HGG, DYR, GXSXG, DPL, and GXIH. Native Est15L was a dimeric form from the results of size exclusion chromatography. It was optimally active at $50{ }^{\circ} \mathrm{C}$ and $\mathrm{pH} 9.0$, indicating alkaline esterase. However, it showed a low thermostability with half-lives of 30.3 at $30{ }^{\circ} \mathrm{C}$ and 2.7 min at $40{ }^{\circ} \mathrm{C}$. It preferred $p$-nitrophenyl butyrate $\left(\mathrm{C}_{4}\right)$ with $\mathrm{K}_{\mathrm{m}}$ and $\mathrm{V}_{\text {max }}$ values of $0.28 \mathrm{mM}$ and $270.8 \mathrm{U} / \mathrm{mg}$, respectively. Est $15 \mathrm{~L}$ was inhibited by organic solvents such as 30\% methanol, isopropanol, and acetonitrile with residual activities of $12.5,0.9$, and $0.3 \%$, respectively. It was also inhibited by $1 \%$ SDS and 1\% PMSF; however, Est15L maintained its activity at 1\% Triton X-100 and EDTA. Est15L was inhibited by $\mathrm{Cu}^{2+}, \mathrm{Zn}^{2+}, \mathrm{Mn}^{2+}, \mathrm{Co}^{2+}, \mathrm{Fe}^{2+}$, and $\mathrm{Na}^{+}$. In addition, Est15L hydrolyzed glyceryl tributyrate with a residual substrate amount of $43.7 \%$ at 60 min but could not hydrolyze the oils (fish and olive) and glyceryl trioleate. Interestingly, Est15L showed significant enantioselectivity toward the $R$-form with a residual substrate amount of $44.6 \%$, lower than that of the $S$-form (83.5\%). Considering its properties, Est15L can be a potential candidate for chemical reactions, such as the synthesis of pharmaceutical compounds.
\end{abstract}

Keywords: Compost Metagenomic library, Family IV esterase, Hormone-sensitive lipase (HSL), Dimeric form, Glyceryl tributyrate hydrolysis, Enantioselectivity

\section{Introduction}

Esterase (EC 3.1.1.1.) is a lipolytic enzyme that hydrolyzes ester bonds to carboxylic acid and alcohols. Bacterial lipolytic enzymes were first classified into eight families by Arpigny and Jaeger according to conserved amino acid sequence motifs and biochemical properties [1]. The lipolytic enzymes have been studied, and recently, family XIX was reported [2].

The family IV esterase is also called hormone-sensitive lipase (HSL) because it showed epinephrine-sensitive

\footnotetext{
*Correspondence: hoon@sunchon.ac.kr

Department of Pharmacy, and Research Institute of Life Pharmaceutical Sciences, Sunchon National University, Suncheon 57922, Republic of Korea
}

activity in human adipose tissue [3]. Family IV esterase belongs to an alpha/beta hydrolase and has $\beta$-sheet structures covered by $\alpha$-helices [4]. The family IV esterase has two domains: a cap domain and a catalytic domain. The role of the cap domain is unknown, but there is a report that the cap domain of family IV esterase is deeply related to the recognition of substrates [5], and the catalytic domain has a catalytic triad: serine (S) in the GXSXG motif, aspartic acid (D), and histidine (H) [6].

Esterase has numerous applications. In particular, esterase can be used for chemical reactions, such as transesterification or production of biodiesel [7], and for ester prodrugs, which have been focused on the application for drug delivery systems to avoid metabolism and side effects [8]. For example, the 2nd-generation 
fluoroquinone antibiotic ciprofloxacin is used for antimicrobial activity against most gram-negative bacteria and many gram-positive bacteria [9]. However, it has low aqueous solubility and intestinal permeability. The introduction of triethylene glycol to ciprofloxacin, which is an ester prodrug, and its use with esterase, increased solubility 400 times, inducing quick hydrolysis and restoration of antimicrobial activity [10]. Additionally, in the case of esterase with enantioselectivity, it is more valuable for the chemical reaction with a specific enantiomer. For example, the statin derivatives-which can be used for various diseases, such as cardiovascular diseasesneed esterase with enantioselectivity and regioselectivity to synthesize them [11].

On the other hand, the metagenome is the genome collected from whole microorganisms in an environment [12]. It is also called environmental DNA (eDNA) because it is collected from a specific environment [13]. Many approaches through a metagenomic library were employed to obtain novel genes because it is possible to predict the diversities and properties of the enzyme from the environment. For the reasons described above, many metagenomic studies have been explored, such as Himalayan glacier frozen soil [14], the saline desert of Kutch [15], freshwater lake [16], caves [17], oil-polluted mud flats [18], and compost [19].

Compost has been selected as an object of metagenomic study because it contains various useful enzymes, such as endoglucanase, xylanase, and esterase [20-22]. We selected the compost metagenome and reported the properties of some lipolytic enzymes obtained from the compost metagenomic library, such as Est2K, Est7K, Est8L, and Est13L [19, 23, 24]. Recently, a family IV esterase from another compost metagenome was reported, and it showed organic solvent stability [25]. In this study, a novel esterase gene, est $15 \mathrm{~L}$, was analyzed, and its encoded enzyme, Est15L, was characterized as a novel member of family IV with efficient enantioselectivity.

\section{Materials and methods Materials}

The compounds isopropylthio- $\beta$-D-galactoside (IPTG) and 5-bromo-4-chloro-3-indolyl- $\beta$-D-galactoside (X-gal) were purchased from Bioneer (Daejeon, Korea). The substrates $p$-nitrophenyl (p-NP) esters $\left(C_{2} \sim C_{16}\right)$, glyceryl triesters (glyceryl tributyrate and glyceryl trioleate), acetylthiocholine iodide (ATCI), S-butyrylthiocholine iodide (BTCI), and 5,5'-dithiobis(2-nitrobenzoic acid) (DTNB) were purchased from Sigma-Aldrich (St. Louis,
MO, USA). HiTrap Q HP (5 mL), t-butyl HIC (1 mL), and HiPrep 16/60 Sephacryl S-200 HR (120 mL) column were purchased from GE Healthcare (Uppsala, Sweden).

\section{A positive esterase clone from the compost metagenomic library}

The metagenome was obtained from Yonghyun Nonghyub Compost Factory (Sachon, Korea), and its library was constructed using the fosmid vector [19]. From this library, 19 esterase-positive clones were obtained on LB agar plates containing $1 \%$ glyceryl tributyrate for $15 \mathrm{~h}$ at $37{ }^{\circ} \mathrm{C}$. They were mixed, digested with a restriction enzyme, cloned with plasmid pUC19, and 18 positive subclones were obtained [19]. By sequencing, nine different lipolytic enzymes were identified, and some of them were reported [19, 23, 24]. In this study, a positive clone YH-E15 was selected for further study.

\section{Sequence analysis of the insert DNA in the positive clone}

DNA sequences of the esterase-positive clone were determined using the Sanger dideoxy method by Solgent (Daejeon, Korea). From this sequence, the ORF similar to esterase was confirmed, and its amino acid sequence was analyzed by BLASTp of NCBI (http://www.ncbi.nlm. nih.gov). Prediction of signal peptide was performed using SignalP 5.0 in CBS (http://www.cbs.dtu.dk/servi ces/SignalP/). Molecular weight and pI were predicted using the ExPASy ProtParam tool (http://web.expasy. org/protparam). Clustal W method of DNA/MAN (Lynnon Biosoft, version 4.11, Quebec, Canada) was used to analyze multiple sequence alignment, and the neighborjoining method in MEGA version X [26] was used to construct the phylogenetic tree. Similarities between the identified enzyme Est15L and other enzymes were calculated using DNA/MAN.

\section{Preparation of crude enzymes}

The clone YH-E15 was cultured in $200 \mathrm{~mL}$ of LB broth containing $50 \mu \mathrm{g} / \mathrm{mL}$ of ampicillin and incubated for $15 \mathrm{~h}$ at $37{ }^{\circ} \mathrm{C}$ and $200 \mathrm{rpm}$. The cell was collected from the cultured medium by centrifuging at $4{ }^{\circ} \mathrm{C}$ and $6,000 \times g$ for $15 \mathrm{~min}$. The collected pellet was washed two times with $20 \mathrm{~mL}$ of $20 \mathrm{mM}$ Tris- $\mathrm{HCl}$ (pH 8.0) buffer by centrifugation at $4{ }^{\circ} \mathrm{C}$ and $6,000 \times g$ for $5 \mathrm{~min}$, resuspended with $5 \mathrm{~mL}$ of the same buffer, sonicated (amplitude of $38 \%$, pulse on for $1 \mathrm{~s}$ and pulse off for $1 \mathrm{~s}$ ) three times using a microtip sonicator (VCX500, Sonics \& Materials, Newtown, CT, USA), and then centrifuged at $4{ }^{\circ} \mathrm{C}$ for $15 \mathrm{~min}$ at $6,000 \times g$. The supernatant was collected as a crude extract. 


\section{Purification of Est15L}

Before the purification step, the crude enzyme was centrifuged for $15 \mathrm{~min}$ at $6,000 \times g$ and $4{ }^{\circ} \mathrm{C}$. The supernatant was loaded to a HiTrap Q anion exchange column in a BioLogic LP system (Bio-Rad, Hercules, CA, USA) with $20 \mathrm{mM}$ Tris- $\mathrm{HCl}(\mathrm{pH} 8.0)$, and the buffer flowed with a linear gradient with a high buffer containing $1 \mathrm{M} \mathrm{NaCl}$ at $1 \mathrm{~mL} / \mathrm{min}$ for $1 \mathrm{~h} 30 \mathrm{~min}$. The active fractions were pooled, dialyzed with $50 \mathrm{mM}$ sodium phosphate (pH 7.0) containing $1.5 \mathrm{M}\left(\mathrm{NH}_{4}\right)_{2} \mathrm{SO}_{4}$ for the t-butyl HIC column as a second column, loaded to the column, and eluted with a high buffer containing $1.5 \mathrm{M}\left(\mathrm{NH}_{4}\right)_{2} \mathrm{SO}_{4}$ with a linear gradient at $1 \mathrm{~mL} / \mathrm{min}$ for $1 \mathrm{~h}$. To confirm the native molecular mass of the enzyme, Sephacryl S-200 size exclusion chromatography was performed using $50 \mathrm{mM}$ sodium phosphate ( $\mathrm{pH} 7.0)$ containing $0.15 \mathrm{M} \mathrm{NaCl}$ at a flow rate of $0.5 \mathrm{~mL} / \mathrm{min}$ for $4 \mathrm{~h}$. $\beta$-Amylase, bovine serum albumin (BSA), and trypsinogen (200, 66.4, and $24.0 \mathrm{kDa}$, respectively) were used as standard markers. During purification, active fractions were loaded on $11.5 \%$ acrylamide gel, and then SDS-PAGE was performed [27]. The concentration of protein was determined by Bradford assay using BSA as a standard [28].

\section{Enzyme assays}

The standard esterase assay was performed using $1 \mathrm{mM}$ $\mathrm{p}-\mathrm{NP}$ butyrate in $50 \mathrm{mM}$ Tris- $\mathrm{HCl}$ (pH 8.0). The amount of $p$-nitrophenol as the product was observed continuously by kinetic mode in a spectrophotometer (OPTIZEN, K-Lab, Daejeon, Korea) for $2 \mathrm{~min}$ at $25^{\circ} \mathrm{C}$ at $400 \mathrm{~nm}$. The molecular extinction coefficient of $p$-nitrophenol used was $16,400 / \mathrm{M} / \mathrm{cm}$ at $\mathrm{pH}$ 8.0. The production of $1 \mu \mathrm{mol} p$-nitrophenol per minute was defined as one unit of an enzyme.

The acetyl-or butyryl-cholinesterase activity was measured by the Ellman method using ATCI or BTCI, respectively, as the substrate, as previously described [29]. Briefly, the enzyme was added to $100 \mathrm{mM}$ sodium phosphate containing $0.5 \mathrm{mM}$ DTNB and $0.5 \mathrm{mM}$ ATCI or BTCI, respectively, and the absorbance of the reaction mixture was observed continuously at $412 \mathrm{~nm}$ for $15 \mathrm{~min}$ at $25^{\circ} \mathrm{C}$ using kinetic mode in spectrophotometer (OPTIZEN).

\section{Characterization of the enzyme}

The standard enzyme assay was characterized using p-NP butyrate with slight modification. For the optimum temperature experiment, the buffer was preheated to 20 , $30,40,50,60$, and $70{ }^{\circ} \mathrm{C}$ prior to assay. For optimum $\mathrm{pH}$, $50 \mathrm{mM}$ Universal buffer (boric acid/ citric acid/ trisodium orthophosphate) for $\mathrm{pH} 6.0$ to 12.0 was used. The molecular extinction coefficients at each $\mathrm{pH}$ were used as previously described [18]. For thermostability, the enzyme was heated for $0,5,10,20,30$, and $60 \mathrm{~min}$ at 30 and $40{ }^{\circ} \mathrm{C}$, added to the assay mixture, and its residual activity was measured.

For the p-NP ester specificity, $1 \mathrm{mM}$ of $\mathrm{p}-\mathrm{NP}$ acetate $\left(\mathrm{C}_{2}\right), \mathrm{p}$-NP butyrate $\left(\mathrm{C}_{4}\right), \mathrm{p}-\mathrm{NP}$ caproate $\left(\mathrm{C}_{6}\right), \mathrm{p}-\mathrm{NP}$ octanoate $\left(\mathrm{C}_{8}\right), \mathrm{p}$-NP decanoate $\left(\mathrm{C}_{10}\right), \mathrm{p}$-NP laurate $\left(\mathrm{C}_{12}\right)$, p-NP myristate $\left(\mathrm{C}_{14}\right)$, and p-NP palmitate $\left(\mathrm{C}_{16}\right)$ were used as substrates for the esterase assay. The kinetic experiment was performed using 0.05, 0.1, 0.2, 0.5, and $1 \mathrm{mM}$ of $\mathrm{C}_{4}$ and a Lineweaver-Burk plot was constructed for measuring $\mathrm{K}_{\mathrm{m}}$ and $\mathrm{V}_{\max }$ values.

Ions such as $\mathrm{NaCl}, \mathrm{KCl}, \mathrm{MgCl}_{2}, \mathrm{CaCl}_{2}, \mathrm{BaCl}_{2}, \mathrm{MnCl}_{2}$, $\mathrm{FeCl}_{2}, \mathrm{CoCl}_{2}, \mathrm{CuCl}_{2}$, and $\mathrm{ZnCl}_{2}$ were added to the assay solution at 2 or $5 \mathrm{mM}$ to confirm the effects of ions. Methanol, isopropanol, and acetonitrile were added to the assay solution to have a final concentration of 5 or $30 \%$ to confirm the effect of the organic solvent. Effects of detergents (such as SDS and Triton X-100) were observed at a concentration of $1 \%$. The effects of inhibitors, such as phenylmethylsulfonyl fluoride (PMSF) and ethylenediaminetetraacetic acid (EDTA), were observed at a concentration of $1 \mathrm{mM}$.

Lipid hydrolysis activity was measured with a $\mathrm{pH}$ shift assay using oils (fish and olive oil) and glyceryl triesters (glyceryl tributyrate and glyceryl trioleate) as substrates [30]. The enzyme was reacted with the substrate in $20 \mathrm{mM}$ Tris- $\mathrm{HCl}(\mathrm{pH}$ 8.0) containing $0.1 \%$ phenol red, and its absorbance at $560 \mathrm{~nm}$ was observed continuously using kinetic mode in the spectrophotometer (OPTIZEN) at $25{ }^{\circ} \mathrm{C}$ for $60 \mathrm{~min}$ at $5 \mathrm{~min}$ intervals. The enantioselectivity was measured using $1 \%(R)$-methyl3-hydroxy-2-methyl-propionate or (S)-methyl-3-hydroxy-methyl propionate as a substrate for the $\mathrm{pH}$ shift assay [18].

\section{In silico 3D modeling}

The prediction of 3D models was conducted using SWISS-MODEL of expasy (https://swissmodel.expasy. org/). The predicted structures were transferred to SwissDock (http://www.swissdock.ch/), and docking simulation was constructed with $(R)$-or $(S)$-methyl-3-hydroxy-2-methyl-propionate (ZINC accession numbers were 395641 and 395640, respectively). Docking data were analyzed using Chimera version 1.15 (https://www. cgl.ucsf.edu/chimera/).

\section{Results}

Sequence analysis and multiple alignments of Est15 L

Due to DNA sequencing for the positive clone YH-E15, it was revealed that insert DNA comprised 2,587 bp, and an open reading frame (ORF) was predicted to be 
an esterase. The ORF was $987 \mathrm{bp}$ in length and named est $15 \mathrm{~L}$. The encoded Est15L esterase comprised 328 amino acids with molecular weights of $34,770 \mathrm{Da}$ with no signal peptide, and its predicted theoretical $\mathrm{pI}$ value was 4.57 . Est15L has been deposited under the accession number of OK336712 in GenBank. In BLASTp, Est15L showed the highest homology (85.03\%) to alpha/ beta hydrolase of Sphingorhabdus sp. (GenBank accession number, MBF6602187) obtained from metagenome-assembled genomes isolated from diarrhea affected cattle B. Conversely, alpha/beta hydrolase of Sphingorhabdus sp. Showed a similar identity (100\%) with Est8L (QZA73595), which was obtained from the compost metagenomic library [24]. Est15L showed relatively low identity to other reported enzymes, and enzymatic properties were characterized in further study.

In the phylogenetic tree, it was confirmed that Est15L is a novel member of family IV esterase (i.e., HSL) (Fig. 1).

Multiple sequence alignment showed several conserved regions-such as HGG $(101 \sim 103)$, DYR (132 134), GXŚAG (174 178), DPL (268 270), and GXII (295 298) — of which the predicted catalytic residues serine $(\mathrm{S})$, aspartic acid $(\mathrm{D})$, and histidine $(\mathrm{H})$ were underlined (Fig. 2).

\section{Purification of Est15L}

Est15L was bound to HiTrap Q and eluted with the linear gradient (Fig. 3A). Specific activity was increased 5.50 times $(24.86 \mathrm{U} / \mathrm{mg})$, compared to the crude extract (4.52 $\mathrm{U} / \mathrm{mg}$ ), with a yield of $24.8 \%$. In size exclusion chromatography using Sephacryl S-200, Est15L was eluted at $61.5 \mathrm{~mL}$, with an increased specific activity of $160.3 \mathrm{U} /$ mg (Fig. 3B; Table 1).

In SDS-PAGE, the predicted band of Est15L, corresponding to about $34.9 \mathrm{kDa}$, was detected in the fractions from Sephacryl S-200 in an activity-dependent manner (Fig. 4). However, it showed smear bands around the major band, along with some minor bands at 100, 75, 48, and $27 \mathrm{kDa}$. Est15L was partially purified using the two chromatographies. Est15L did not bind to other resins (such as CHT-II, High S, and t-butyl HIC) and showed low yields of less than $8.7 \%$.

From the elution volume, the molecular mass of Est15L was calculated to be $67.2 \pm 8.8 \mathrm{kDa}$, and it can be predicted that native Est15L existed as a dimeric form (Fig. 3B; Table 2).

\section{Characterization of Est15L}

Est $15 \mathrm{~L}$ was optimally active at $50{ }^{\circ} \mathrm{C}$ and $\mathrm{pH}$ 9.0, indicating Est15L was an alkaline esterase (Fig. 5A, B). In

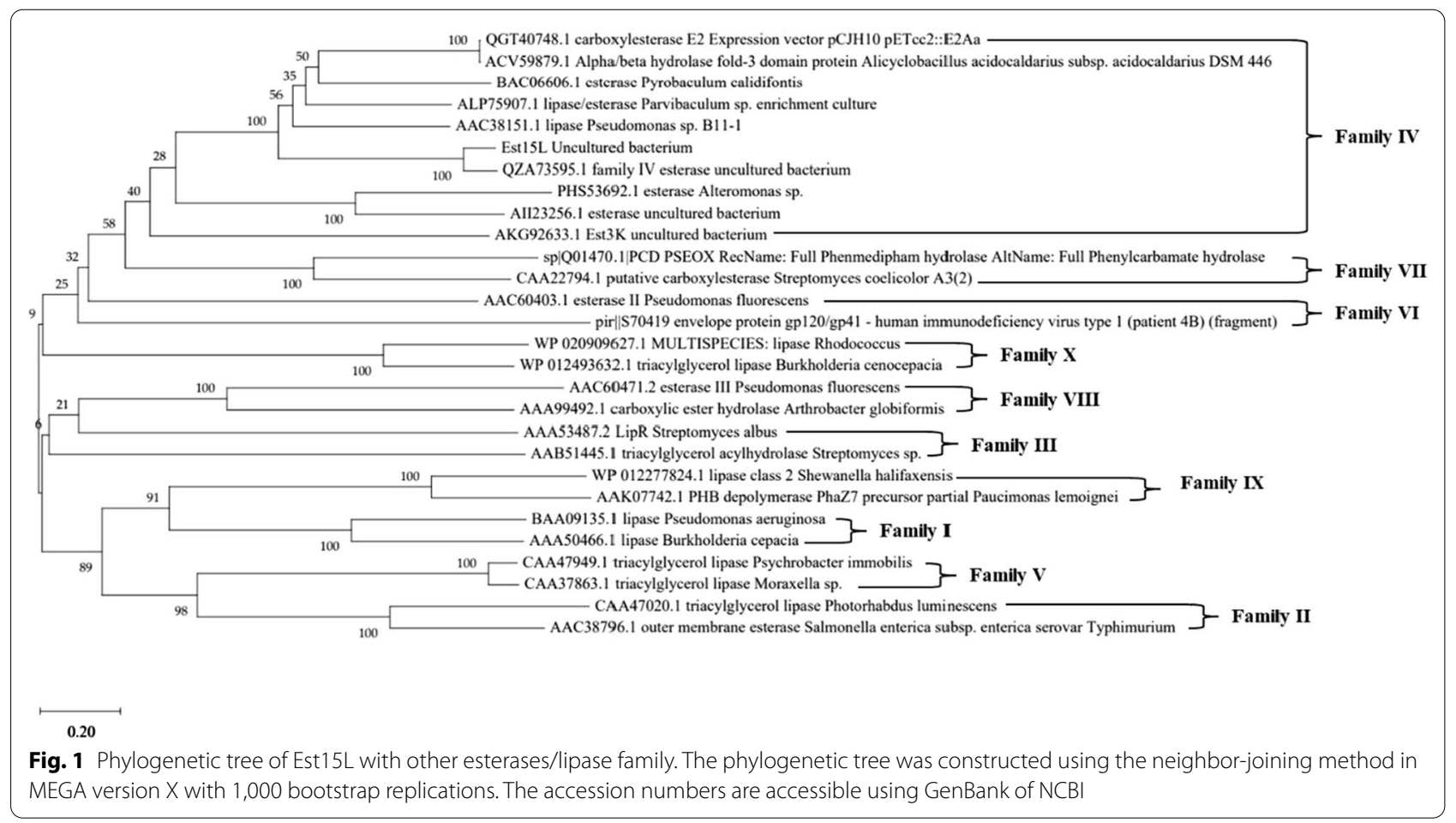




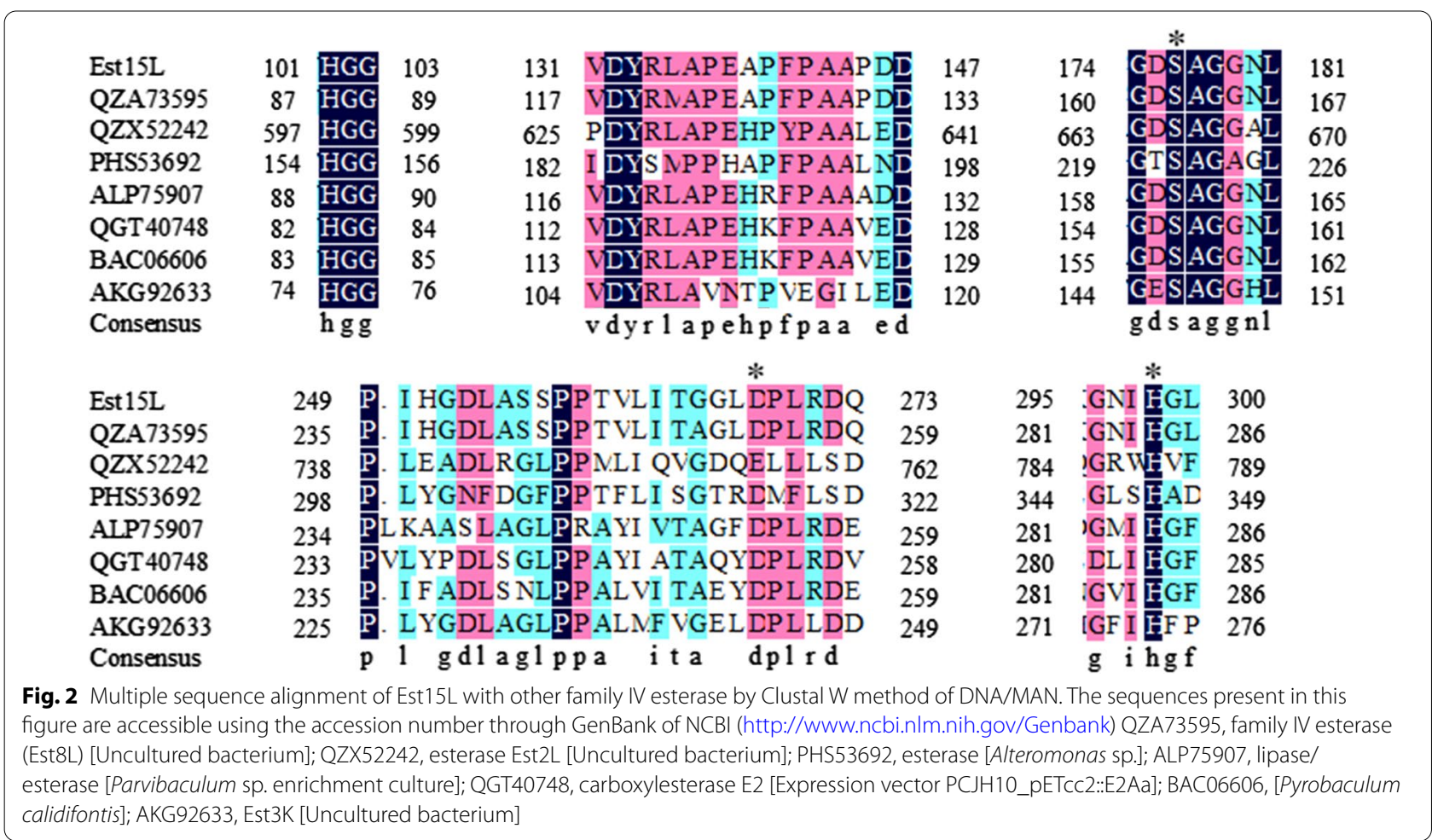

thermostability, Est15L was sensitive to thermal stress with half-lives of $2.7 \mathrm{~min}$ at $40{ }^{\circ} \mathrm{C}$ and $30.3 \mathrm{~min}$ at $30{ }^{\circ} \mathrm{C}$ (Fig. 5C).

Est15L preferred $\mathrm{C}_{4}$ followed by $\mathrm{C}_{6}, \mathrm{C}_{8}$, and $\mathrm{C}_{2}$ with relative activities of $69.3,49.3$, and $35.8 \%$, respectively (Fig. 6A). On the other hands, Est15L did not show $\mathrm{AChE}$ and BChE activities. In a kinetic study using $\mathrm{C}_{4}$, $\mathrm{K}_{\mathrm{m}}$ and $\mathrm{V}_{\max }$ values of Est15L were $0.28 \pm 0.02 \mathrm{mM}$ and $278.0 \pm 10.9 \mathrm{U} / \mathrm{mg}$, respectively (Fig. 6B).

In the presence of $30 \%$ methanol, isopropanol, and acetonitrile, Est15L activity was significantly inhibited to $12.5,0.9$, and $0.3 \%$, respectively. In detergent, Est $15 \mathrm{~L}$ activity was maintained to $88.2 \%$ at $1 \%$ Triton X-100. However, it was extensively inactivated to $0.38 \%$ at $1 \%$ SDS. In the case of inhibitors, Est15L was stable at $1 \mathrm{mM}$ EDTA with a relative activity of $89.9 \%$ but was strongly inhibited to $2.5 \%$ by $1 \mathrm{mM}$ PMSF (Fig. 7A).

Est15L was inhibited by metal ions (i.e., $2 \mathrm{mM}$ of $\mathrm{Zn}^{2+}$, $\mathrm{Co}^{2+}$, and $\mathrm{Na}^{+}$) with residual activities of $16.6,47.3$, and $52.5 \%$, respectively. It was also inhibited by $5 \mathrm{mM}$ of $\mathrm{Cu}^{2+}, \mathrm{Mn}^{2+}$ and $\mathrm{Fe}^{2+}$ with relative activities of 5.5, 30.1, and $49.8 \%$, respectively. No activations were observed with any metal ions (Fig. 7B).

Est15L efficiently hydrolyzed glyceryl tributyrate with a residual substrate amount of $43.7 \%$. However, no significant hydrolysis activity was observed for olive oil, fish oil, and glyceryl trioleate (Fig. 8A). Interestingly, Est15L showed higher enantioselectivity toward the $R$-form with a residual substrate amount of $44.6 \%$ than toward the $S$-form with $83.5 \%$ after a 60 min reaction (Fig. 8B).

\section{Discussion}

In this study, an esterase Est15L, a novel member of family IV (HSL family), was obtained from a compost metagenomic library. Est15L showed the highest similarity (85.03\%) to alpha/beta hydrolase of Sphingorhabdus sp. (MBF06602187) and Est8L, and the properties of Est8L were reported in our previous study [24]. Though Est15L and Est8L showed high similarity of amino acid sequence, their properties were different from each other, such as optimum temperature $\left(50\right.$ vs. $\left.40{ }^{\circ} \mathrm{C}\right)$, thermostability (half-lives of $2.7 \mathrm{~min}$ at $40{ }^{\circ} \mathrm{C}$ vs. $3.2 \mathrm{~min}$ at $50{ }^{\circ} \mathrm{C}$ ), enantioselectivity ( $R$-form vs $S$-form), and organic solvents effect. It has been reported that some lipolytic enzymes showed different properties in a specific activity, enantioselectivity, ionic effect, and organic solvent effect, despite high similarities of their amino acid sequences $[18,24,31-34]$. 


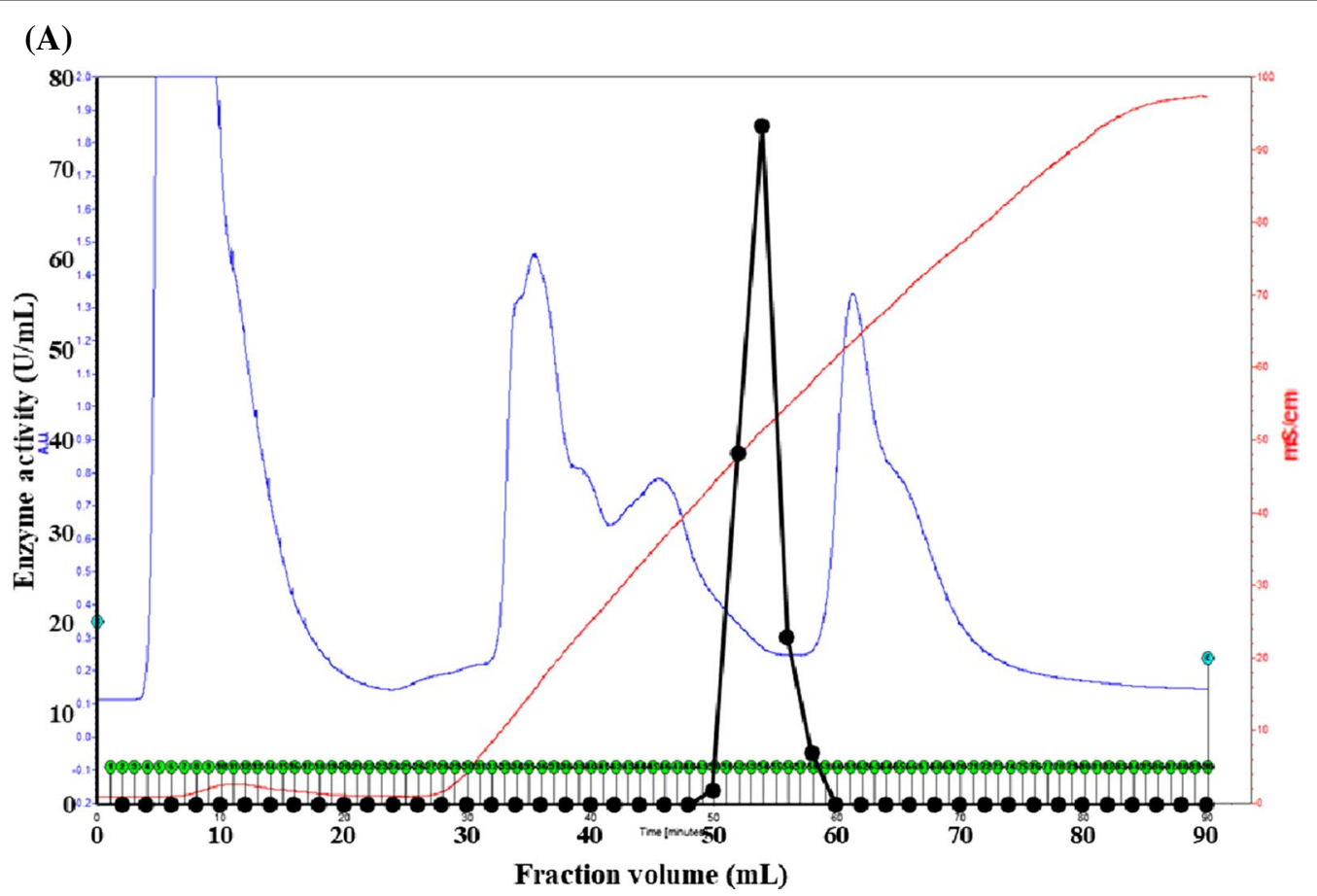

(B)

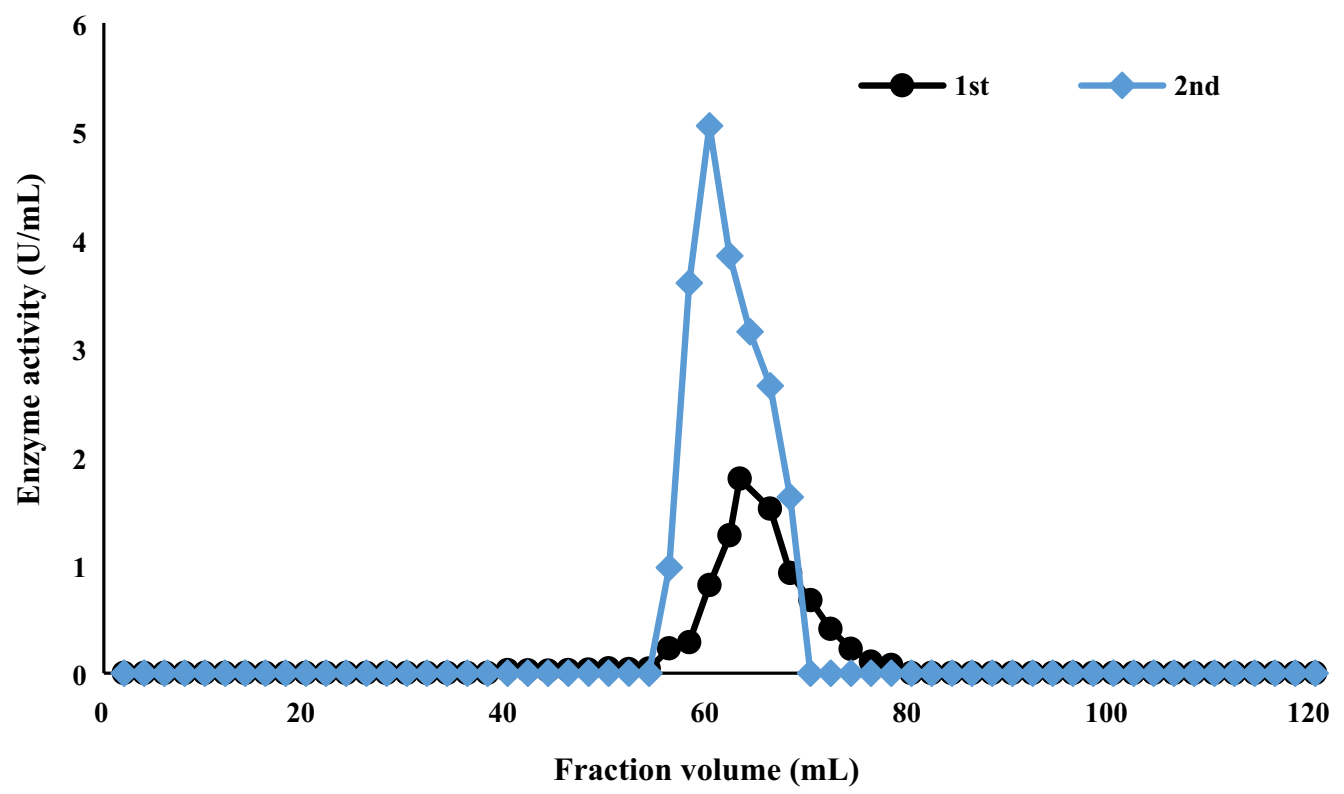

Fig. 3 HiTrap Q (A) and Sephacryl S-200 (B) chromatograms of Est15L. The blue, red, and black lines of the HiTrap Q chromatogram indicate the absorbance at $280 \mathrm{~nm}$ (A.U.), conductivity (dS/cm), and esterase activity $(\mathrm{U} / \mathrm{mL})$, respectively. The size exclusion chromatography by Sephacryl S-200 was performed twice, and pools from the 2nd experiment were used for SDS-PAGE 
Table 1 The specific activity and yield of Est15L at purification steps

\begin{tabular}{lcll}
\hline Preparation & $\begin{array}{l}\text { Specific activity } \\
(\mathbf{U} / \mathbf{m g})\end{array}$ & $\begin{array}{l}\text { Purification } \\
\text { (fold) }\end{array}$ & Yield (\%) \\
\hline Crude extract & 4.52 & 1 & 100 \\
HiTrap Q & 24.86 & 5.50 & 24.8 \\
Sephacryl S-200 & 160.3 & 35.5 & 19.3 \\
\hline
\end{tabular}

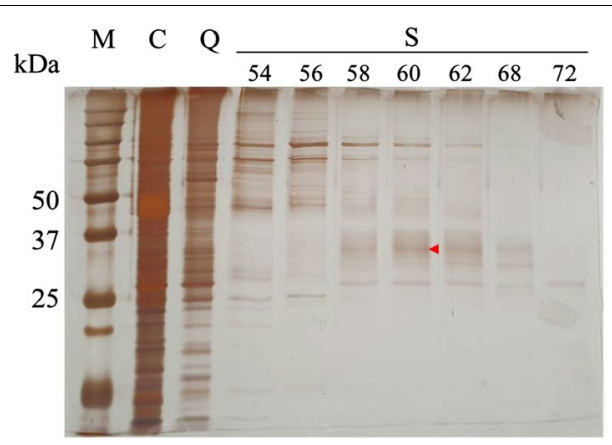

Fig. 4 SDS-PAGE of Est15L stained with silver nitrate. An active fraction with the highest activity from HiTrap $Q$ and active fractions from Sephacryl S-200 were used for the experiment. The red arrow in the figure represents the predicted position of the Est15L ( 34.9 kDa). $\mathrm{M}$, size marker; C, crude extract; $\mathrm{Q}$, the fraction from HiTrap Q (number 54 in Fig. 3A); S, fractions from Sephacryl S-200 (numbers 54, $56,58,60,68$, and 72 in Fig. 3B)

Table 2 The molecular mass of native Est15L determined by size exclusion chromatography

\begin{tabular}{llll}
\hline & $\begin{array}{l}\text { Elution volume } \\
(\mathbf{m L})\end{array}$ & $\begin{array}{l}\text { Molecular mass } \\
(\mathbf{k D a})\end{array}$ & $\log \mathbf{M w}$ \\
\hline$\beta$-amylase & 46 & 200 & 2.30 \\
BSA & 58 & 66.4 & 1.82 \\
Trypsinogen & 78 & 24.0 & 1.38 \\
Est15L & 61.5 & $67.2 \pm 8.8$ & 1.83 \\
\hline
\end{tabular}

The means \pm SEs were calculated with duplicate experiments

In predictions of 3D structure models, Est15L showed the highest identity (33.89\%) to Esterase Crystal structure of Chloramphenicol-Metabolizing Enzyme EstDL 136-Chloramphenicol complex (PDB code: 6iey.1.A) homo-dimer form. Est8L showed the highest identity (33.55\%) to Esterase Crystal structure of Chloramphenicol-Metabolizing Enzyme EstDL 136 (PDB code: 6aae.1.A) with homo-dimer form. In the predicted model, the N-terminal of Est15L (M1 A18) was not predicted because it did not identify with other family IV esterase; thus, its structure could not be predicted. The Chain A of Est15L comprised $11 \alpha$-helix and $8 \beta$-sheets, and Chain B comprised $9 \alpha$-helix and $8 \beta$-sheets (Fig. 9A, C). Moreover, the Chain A of Est8L comprised $12 \alpha$-helix and $8 \beta$-sheets, and Chain B of Est8L comprised 11 $\alpha$-helix and $8 \beta$-sheets (Fig. 9B, D). In the case of $\beta$-sheet structures, no difference was found between Est15L and Est8L. However, Est15L has three fewer $\alpha$-helix structures than Est8L; that is, the motifs F42 T49 of Chain B, A129 E143 of Chain A, and L286 L289 in Est8L were predicted as $\alpha$-helical structures, whereas Est15L did not show (Fig. 9). Its structural differences might occur in biochemical properties such as optimum temperature, thermostability, and enantioselectivity.

By using the model templates as above, docking simulations of Est15L and Est8L with $(R)$ - or $(S)$-methyl3-hydroxy-2-methyl-propionate were performed. Interestingly, Est15L showed a higher affinity with the $(R)$-form $(\Delta \mathrm{G}=-6.31 \mathrm{kcal} / \mathrm{mol})$ than $(S)$-form $(\Delta \mathrm{G}=-$ $6.23 \mathrm{kcal} / \mathrm{mol}$ ) at cap domain for the strongest binding, which is considered to have an important role in recognition of the substrate (Additional file 1: Table S1). However, Est8L, showing $(S)$-form selectivity, also showed a higher affinity with the $(R)$-form, $(\Delta \mathrm{G}=-6.92 \mathrm{kcal} / \mathrm{mol})$ than with the $(S)$-form, $(\Delta \mathrm{G}=-6.87 \mathrm{kcal} / \mathrm{mol})$ (Additional file 1: Table S2). In addition, no interaction or binding was predicted between the catalytic triads of the enzymes and their substrates, except that the $(S)$-form formed a hydrogen bond with Ser176 of Est15L, at a distance of $3.082 \AA(\Delta \mathrm{G}=-6.22 \mathrm{kcal} / \mathrm{mol}$ ) (Additional file 1: Figure S1). Collectively, though the docking values could not sufficiently support the selectivity, it is suggested that other bindings may contribute to their selectivity at the same time.

The other family IV esterase from a compost metagenomic library, EstCS1, was recently reported, and it showed similar properties to Est15L, such as optimum temperature $\left(50{ }^{\circ} \mathrm{C}\right)$, substrate specificity $\left(\mathrm{C}_{4}\right.$ vs. $\left.\mathrm{C}_{3}\right)$, and optimum $\mathrm{pH}$ (9.0 vs. 8.0). However, Est15L showed lower stability $(<12.5 \%$ residual activity) toward organic solvents (i.e., at $30 \%$ methanol, isopropanol, and acetonitrile) than EstCS1 (>90.8\% residual activity) [25]. Moreover, the enantioselectivity of EstCS1 was not reported [25] (Table 3).

Compared to other esterases characterized to date, Est15L showed low identities from 3.17 to $30.72 \%$ [3539]. The molecular weights of family IV esterases ranged from 30.4 to $41.2 \mathrm{kDa}$ [40-42], except for Est2L, which was a fusion-type protein with a molecular weight of $92.5 \mathrm{kDa}$ [43]. This indicates that the molecular weight of Est15L is an average value. Native Est15L was a dimeric form, as most family IV esterases reported [44-46], except that AFEST, EST2, and EstE5 were monomeric 
(A)

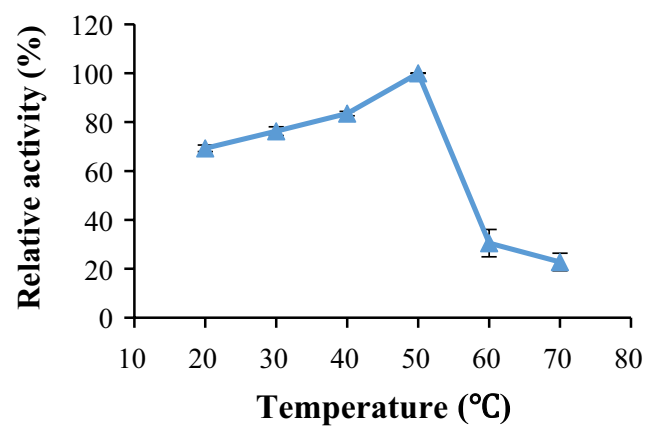

(B)

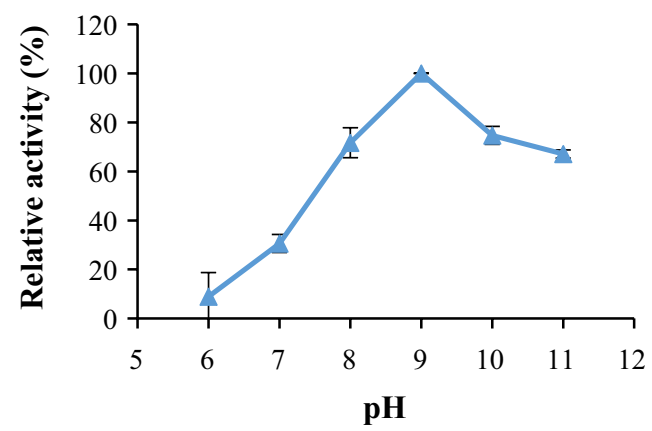

(C)

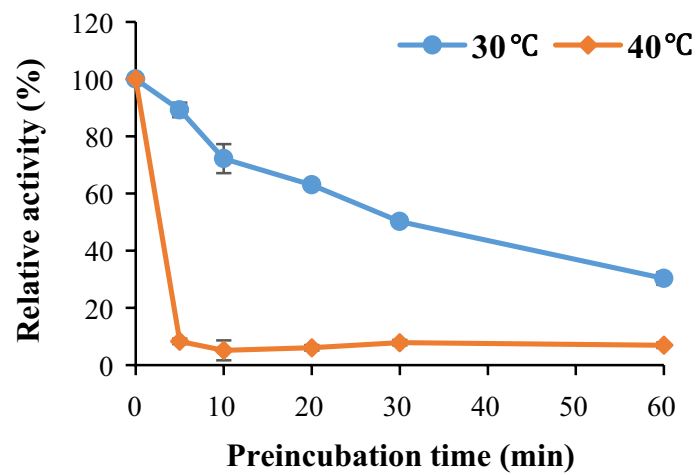

Fig. 5 The optimum temperature $(\mathbf{A})$ and $\mathrm{pH}(\mathbf{B})$, and thermostability $(\mathbf{C})$ of Est15L. For optimum temperature experiment, $50 \mathrm{mM} \mathrm{Tris-HCl}(\mathrm{pH} 8.0)$ buffer was preheated to designated temperatures. For optimum pH, $50 \mathrm{mM}$ Universal buffer (boric acid/citric acid/trisodium orthophosphate, pH 6.0 to 11.0) was used. For thermostability, Est15L was preincubated for designated times without substrate prior to the standard assay

(A)

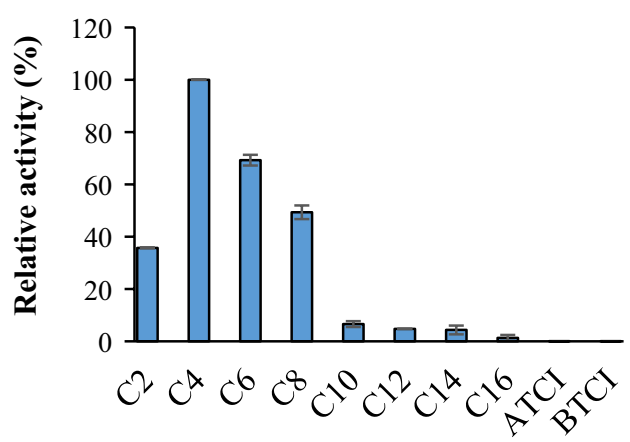

(B)

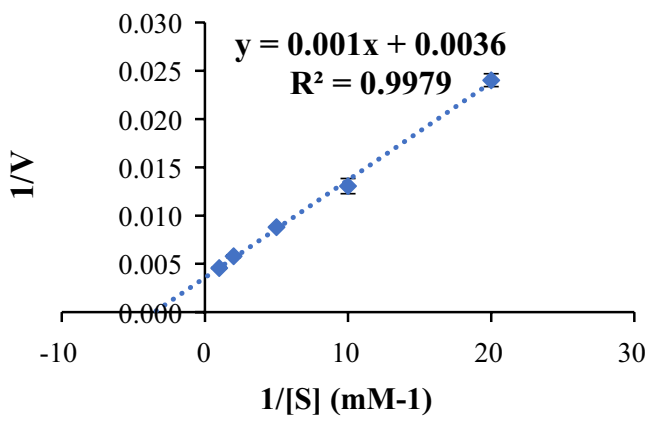

Fig. 6 Substrate specificity (A) and Lineweaver-Burk plot (B) of Est15L. For substrate specificity, p-NP esters were used for esterase assay at $1 \mathrm{mM}$. For the cholinesterase assay, $0.5 \mathrm{mM}$ substrates were used. Kinetic study was performed using $0.05,0.1,0.2,0.5$, and $1.0 \mathrm{mM}$ of $\mathrm{C}_{4}$ 
(A)

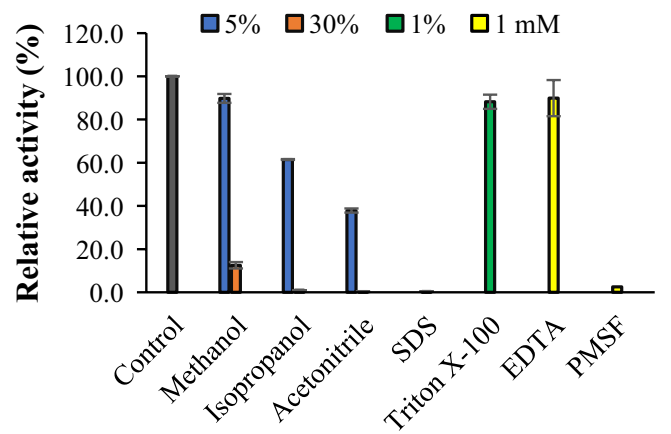

(B)

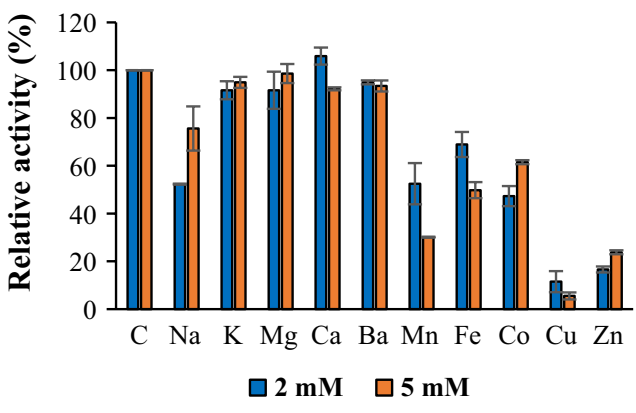

Fig. 7 Effects of organic solvents, detergents, inhibitors (A), and ions (B) on Est15L activity. The effectors were added to the standard esterase assay solution

(A)

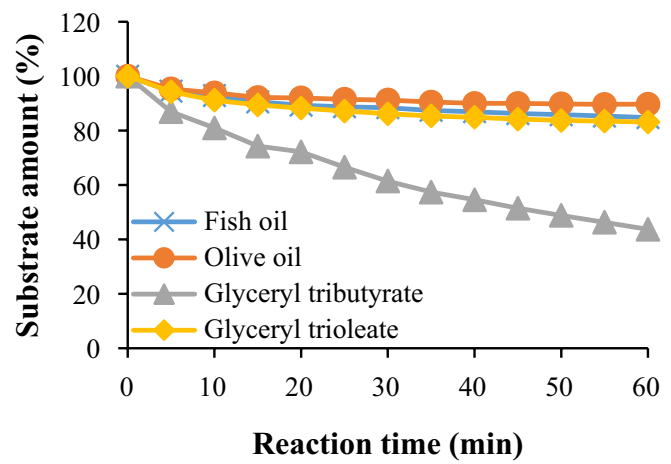

(B)

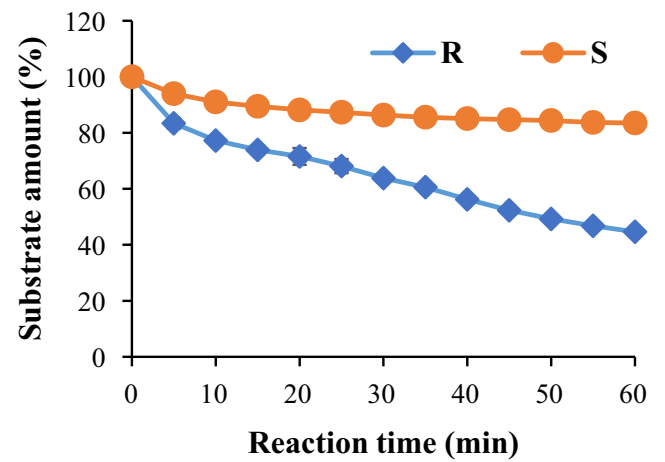

Fig. 8 Lipid hydrolysis activity (A) and enantioselectivity (B) of Est15L. Substrates, that is, 1\% of oils, glyceryl triesters, and (R)- or (S)-methyl-3-hydrox $\mathrm{y}$-2-metyhl-propionate isomers, were added to the solution for the $\mathrm{pH}$ shift assay

forms [38, 39, 41, 47], and Cest-2923 and E40 were tetrameric forms [40, 48, 49] (Table 3). On the other hand, REst1 exists in two types: monomeric form and trimeric form [50].

The specific activity of Est15L (160.3 U/mg) was the average of most family IV esterases [35, 36, 51, 52], and was 2.4 times lower than Est8L (388.6 U/mg), which has high similarity to Est15L. Some of family IV esterases had significantly high specific activities: PestE (3,910 U/mg), AFEST (3,000 U/mg), Est22 (2,065 U/mg), and Rv1399c (1,350 U/mg) [38, 39, 53-56] (Table 3).

The optimum temperature of Est15L was in the range of most family IV esterases from 25 to $60{ }^{\circ} \mathrm{C}[51,57,58]$, although some of them were thermophilic: EstE1 $\left(95^{\circ} \mathrm{C}\right)$, PestE $\left(90{ }^{\circ} \mathrm{C}\right)$, and SaHSL $\left(70{ }^{\circ} \mathrm{C}\right)[53,54,59,60]$. Est15L was alkaline, likely to most family IV esterases, that is, alkaline, or neutral esterase [51, 61, 62], except for EstE1, EstE7, Sto-Est, Est3, and EstB28 [59, 63-67] (Table 3).

Est15L had no signal peptide, likely most of the family IV esterase, suggesting Est15L is an intracellular esterase, but EstA1 had a signal peptide [42].

In the case of substrate specificity, Est15L preferred short-length substrates, likely most of family IV esterase $\left(C_{2}\right.$ to $\left.C_{6}\right)[35,36,60,68]$. However, Sto-Est and EstAG1 


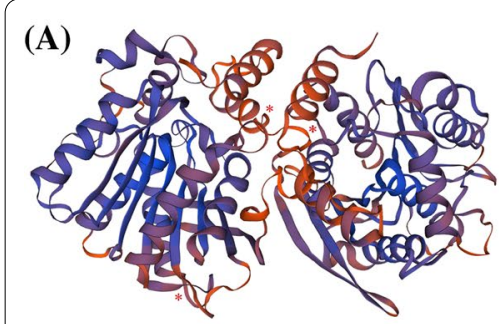

(C)

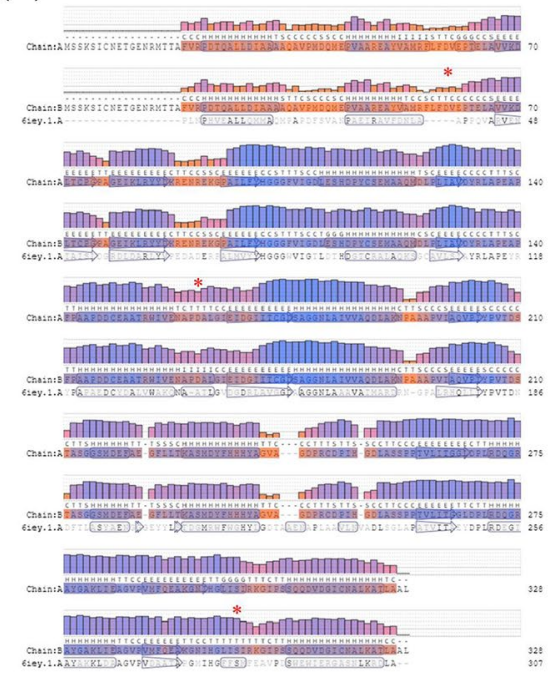

(D)

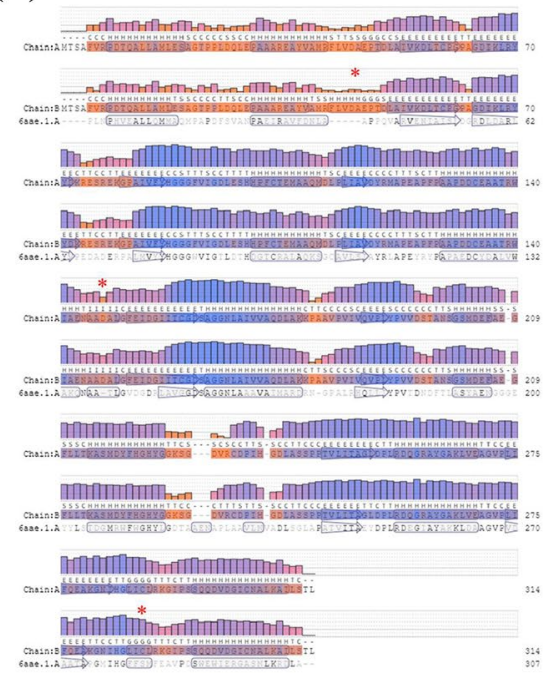

Fig. 9 Predicted 3D models of Est15L (A) and Est8L (B) and model template alignments of Est15L (C) and Est8L (D). The predicted 3D models were constructed using SWISS-MODEL (https://swissmodel.expasy.org/). The model template for $\mathbf{A}$ and $\mathbf{C}$ of Est15L was the Esterase Crystal structure of Chloramphenicol-Metabolizing Enzyme EstDL 136-Chloramphenicol complex (PDB code: 6iey.1.A) and that for $\mathbf{B}$ and $\mathbf{D}$ of Est8L was the Esterase Crystal structure of Chloramphenicol-Metabolizing Enzyme EstDL 136 (PDB code: 6aae.1.A). The differences between Est15L and Est8L are marked as red star marks

showed the highest activity toward medium-length $\mathrm{C}_{8}$ $[66,69]$. The organic solvents such as methanol, isopropanol, and acetonitrile inhibited most family IV esterases, except some of them were solvent-tolerant, such as EstCS1, EstA1, and PestE [24, 42, 53, 54] (Table 3).

The metal ion effects of family IV esterases are diverse; Est15L showed inhibitions by $\mathrm{Cu}^{2+}, \mathrm{Zn}^{2+}, \mathrm{Mn}^{2+}, \mathrm{Co}^{2+}$, and $\mathrm{Na}^{+}$and similar patterns with Est8L, except for $\mathrm{Mn}^{2+}$ and $\mathrm{Na}^{+}$. Similar effects of metal ions were reported for SAestA, EstKT7, DMWf18-543, and DMWf18-558 [57, 68, 70] (Table 3).

Est15L showed great enantioselectivity toward the $R$-form (38.90\% higher than the $S$-form), whereas Est8L showed an $S$-form preference. The $R$-form enantioselectivity of Est15L was similar to PestE, a family IV esterase; however, Est15L was different from PestE in specific activity (160.3 vs. $3,910 \mathrm{U} / \mathrm{mg}$ ), optimum $\mathrm{pH}(9.0$ vs. 7.0$)$, substrate preference $\left(\mathrm{C}_{4}\right.$ vs. $\left.\mathrm{C}_{6}\right)$, and optimum temperature $\left(50\right.$ vs. $\left.90{ }^{\circ} \mathrm{C}\right)[53,54]$ (Table 3 ). Enantioselective esterases can be used for purifying and enriching the specific enantiomer [71]. For example, the lipolytic enzyme from pseudomonas cepacia is a popular catalyst for hydrolysis, transesterification, and esterification of racemic mixtures of secondary alcohols to synthesize important enantiomers [72]. Est15L can be used for purifying the racemic mixtures to enrich the $(S)$-form enantiomer by selective hydrolysis of the $(R)$-form enantiomer.

Collectively, Est15L was sensitive to organic solvents, ions, and thermal stress, but it showed good specific activity and enantioselectivity. In this study, Est15L was obtained from a compost metagenomic library, and its 


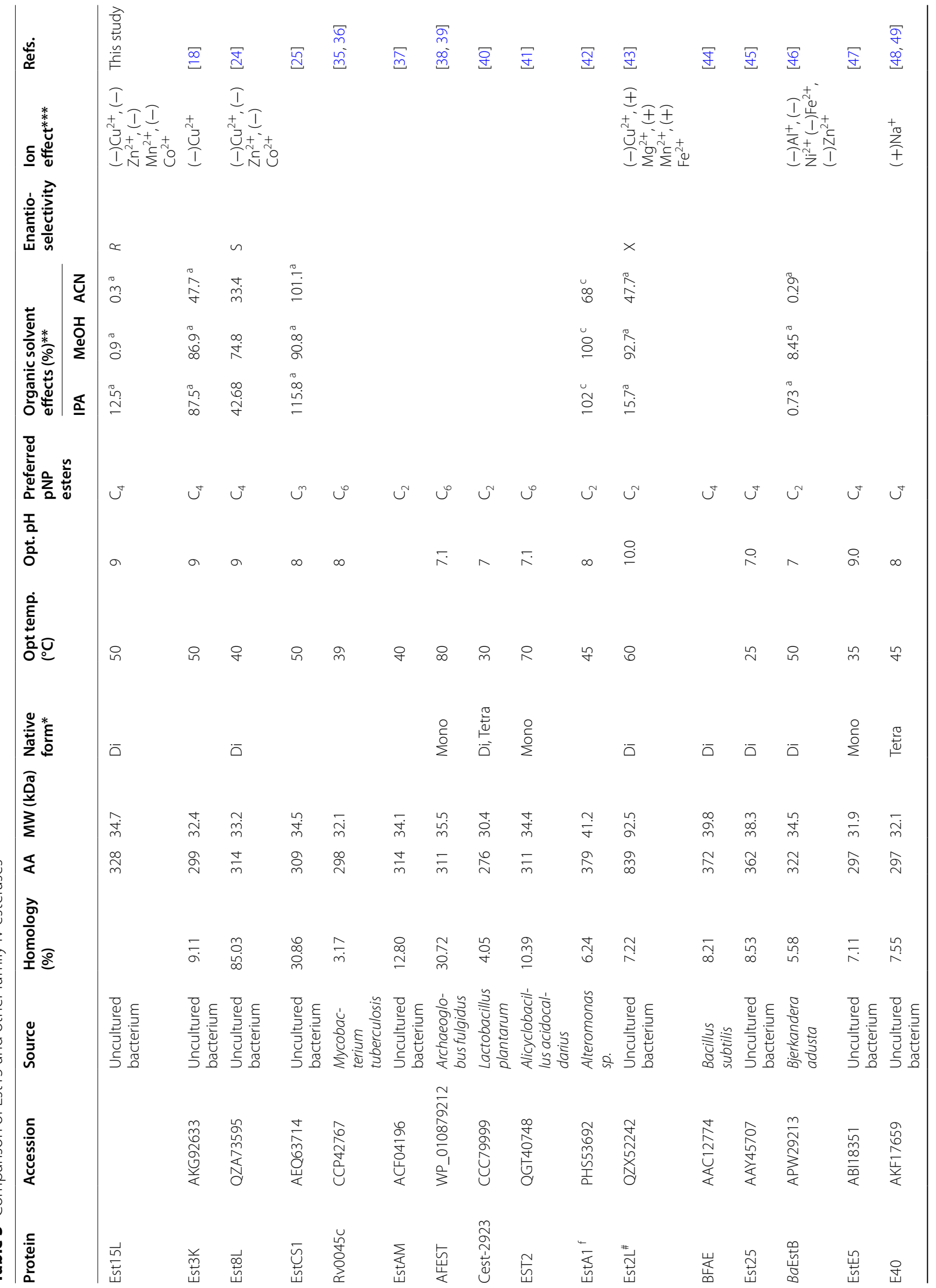




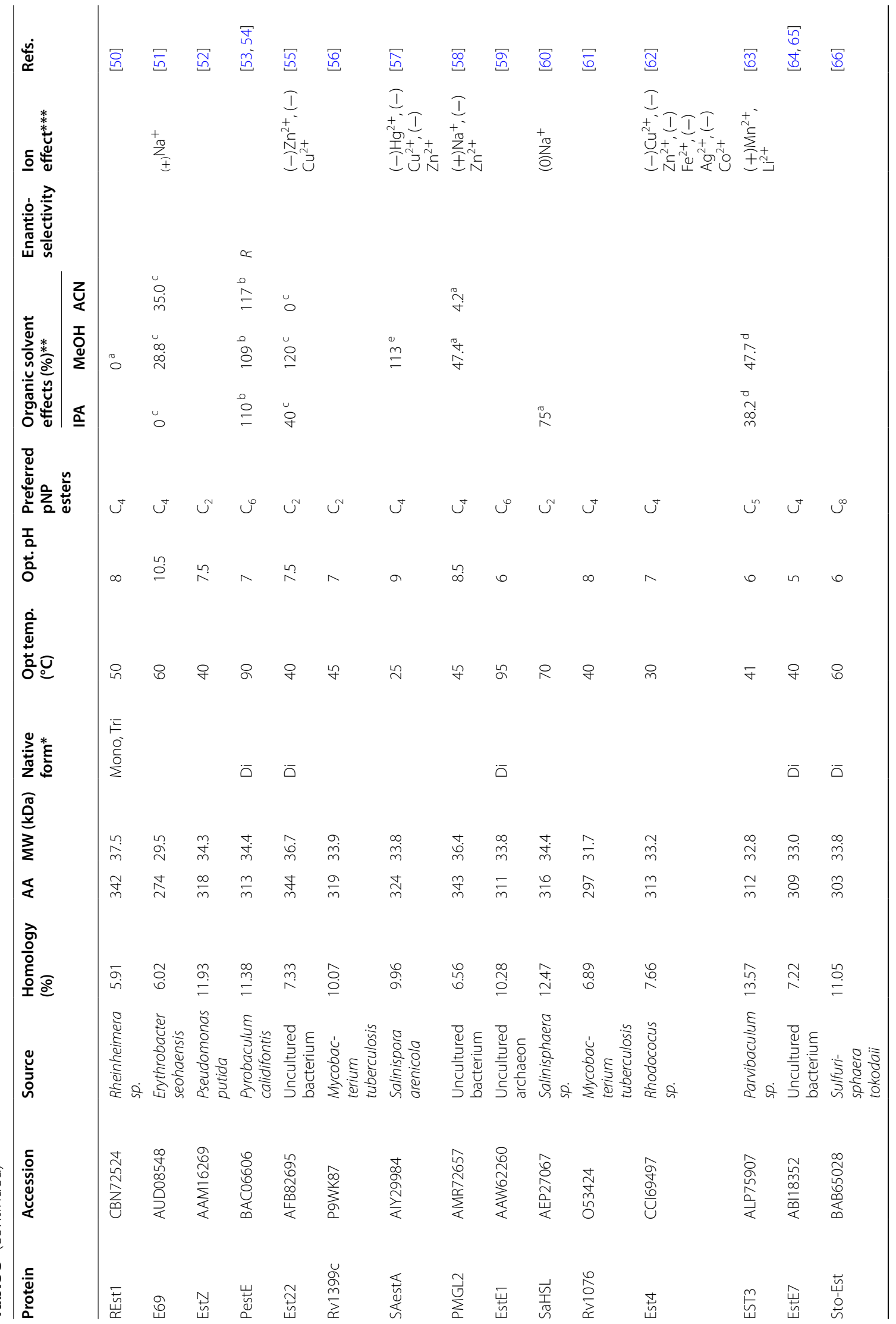




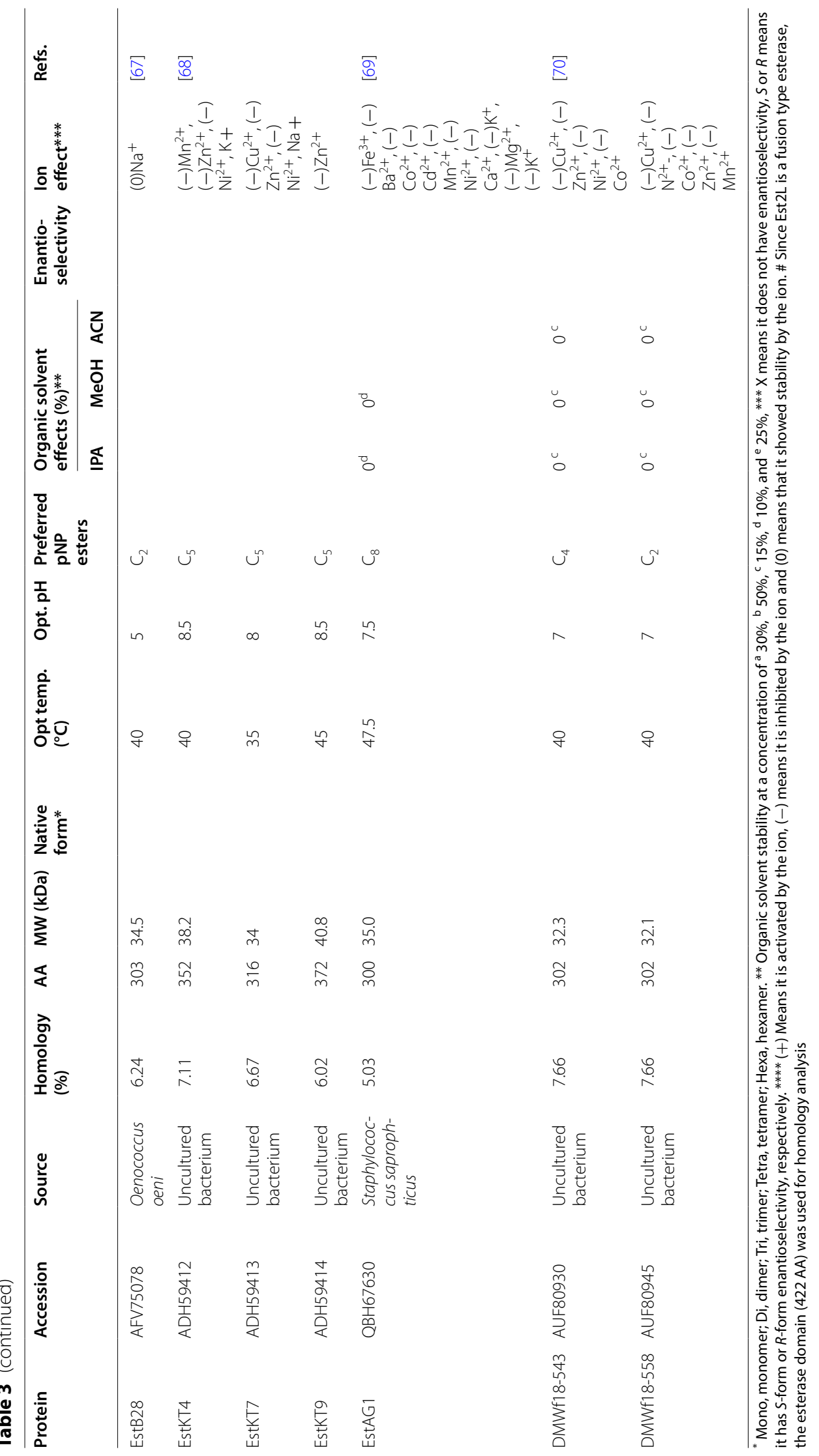


enzymatic properties were characterized. Est15L was a novel protein and showed the highest similarity (85.03\%) with an alpha/beta hydrolase of Sphingorhabdus sp. and Est8L. Though Est15L and Est8L showed high similarity, their properties were different from each other: optimum temperature (50 vs. $40{ }^{\circ} \mathrm{C}$ ), thermostability (half-lives, 2.7 $\min$ at $40^{\circ} \mathrm{C}$ vs. $3.2 \mathrm{~min}$ at $\left.50{ }^{\circ} \mathrm{C}\right)$, specific activity $(160.3$ vs. $388.6 \mathrm{U} / \mathrm{mg}$ ), and enantioselectivity ( $R$ - vs. $S$-form). Est15L was sensitive to organic solvents such as methanol, isopropanol, and acetonitrile, whereas Est8L was relatively tolerant to them. On the other hands, Est15L had great enantioselectivity with a residual substrate amount of $43.68 \%$ for the $R$-form. We tracked why these differences are occurred by predicting $3 \mathrm{D}$ structures and docking simulations, and we found structural differences between Est15L and Est8L, i.e., three less $\alpha$-helices and longer cap domain of Est15L, which showed higher affinity with $R$-form in docking simulation. Although Est15L is less stable to ionic and thermal stress than Est8L, the enantioselectivity of Est15L will be more valuable for chemical applications. These results suggest that Est15L is a novel member of family IV esterase and a potential candidate of the chemical reaction or ester prodrugs with enantioselectivity.

\begin{abstract}
Abbreviations
HSL: Hormone-sensitive lipase; IPTG: Isopropylthio- $\beta$-D-galactoside; $X$-gal: 5-Bromo-4-chloro-3-indolyl- $\beta$-D-galactoside; $\mathrm{p}$-NP: $p$-Nitrophenyl; $C_{2}$ : $p$-Nitrophenyl acetate; $C_{4}$ : $p$-Nitrophenyl butyrate; $C_{6}$ : $p$-Nitrophenyl caproate; $C_{8}$ : $p$-Nitrophenyl octanoate; $C_{10}$ : $p$-Nitrophenyl decanoate; $C_{12}$ : $p$-Nitrophenyl laurate; $C_{14}$ : $p$-Nitrophenyl myristate; $C_{16}$ : $p$-Nitrophenyl palmitate; $A T C l$ : Acetylthiocholine iodide; BTCl: S-Butyrylthiocholine iodide; DTNB: 5,5'-Dithiobis(2nitrobenzoic acid); ORF: Open reading frame; BSA: Bovine serum albumin; SDS-PAGE: Sodium dodecyl sulfate polyacrylamide gel electrophoresis; PMSF: Phenylmethylsulfonyl fluoride; EDTA: Ethylenediaminetetraacetic acid.
\end{abstract}

\section{Supplementary Information}

The online version contains supplementary material available at https://doi. org/10.1186/s13765-021-00653-y.

\section{Additional file 1: Table S1. Docking values of Est15L and (R)- or (S)-} methyl-3-hydroxy-2-methyl-propionate. Table S2. Docking values of Est8L and $(R)$ - or (S)-methyl-3-hydroxy-2-methyl-propionate. Figure S1. Docking simulation of Est15L and (S)-methyl-3-hydroxy-2-methyl-propionate. The docking data were analyzed with Chimera version 1.15, and then interaction between catalytic residues of Est $15 \mathrm{~L}$ and the substrate was predicted at cluster 1.

\section{Acknowledgements}

Not applicable

\section{Authors' contributions}

Conceptualization: HK, Cloning: HWL, Purification: GSJ, JEP, Analysis of enzymatic property: GSJ, JEP, Data curation: JEP, Writing-original draft preparation: JEP, Writing-review and editing: HK, Supervision: HK. All authors have read and approved the final manuscript.

\section{Funding}

This work was supported by a Research Promotion Program of SCNU.
Availability of data and materials

All data generated or analyzed during the present study are included in this published article.

\section{Declarations}

\section{Competing interests}

The authors declare that they have no competing interests.

Received: 5 October 2021 Accepted: 16 November 2021

Published online: 27 November 2021

\section{References}

1. Arpigny JL, Jaeger KE (1999) Bacterial lipolytic enzymes: classification and properties. Biochem J 343(Pt 1):177-183

2. Parapouli M, Foukis A, Stergiou PY, Koukouritaki M, Magklaras P, Gkini OA, Papamichael EM, Afendra AS, Hatziloukas E (2018) Molecular, biochemical and kinetic analysis of a novel, thermostable lipase (LipSm) from Stenotrophomonas maltophilia Psi-1, the first member of a new bacterial lipase family (XVIII). J Biol Res (Thessalon) 25:4. https://doi.org/10.1186/ s40709-018-0074-6

3. Kraemer FB, Shen WJ (2002) Hormone-sensitive lipase: control of intracellular tri-(di-)acylglycerol and cholesteryl ester hydrolysis. J Lipid Res 43(10):1585-1594. https://doi.org/10.1194/jlr.r200009-j|r200

4. Ollis DL, Cheah E, Cygler M, Dijkstra B, Frolow F, Franken SM, Harel M, Remington SJ, Silman I, Schrag J (1992) The alpha/beta hydrolase fold. Protein Eng 5(3):197-211. https://doi.org/10.1093/protein/5.3.197

5. Höppner A, Bollinger A, Kobus S, Thies S, Coscolín C, Ferrer M, Jaeger KE, Smits $S$ (2021) Crystal structures of a novel family IV esterase in free and substrate-bound form. FEBS J 288(11):3570-3584. https://doi.org/10. 1111/febs.15680

6. Hong KH, Jang WH, Choi KD, Yoo OJ (1991) Characterization of Pseudomonas fluorescens carboxylesterase: cloning and expression of the esterase gene in Escherichia coli. Agric Biol Chem 55(11):2839-2845

7. López-López O, Cerdán ME, González-Siso MI (2015) Thermus thermophilus as a source of thermostable lipolytic enzymes. Microorg 3(4):792-808. https://doi.org/10.3390/microorganisms3040792

8. McGoldrick CA, Jiang YL, Paromov V, Brannon M, Krishnan K, Stone WL (2014) Identification of oxidized protein hydrolase as a potential prodrug target in prostate cancer. BMC Cancer 14:77. https://doi.org/10.1186/ 1471-2407-14-77

9. Chin NX, Neu HC (1984) Ciprofloxacin, a quinolone carboxylic acid compound active against aerobic and anaerobic bacteria. Antimicrob Agents Chemother 25(3):319-326. https://doi.org/10.1128/AAC.25.3.319

10. Larsen EM, Johnson RJ (2019) Microbial esterases and ester prodrugs: an unlikely marriage for combating antibiotic resistance. Drug Dev Res 80(1):33-47. https://doi.org/10.1002/ddr.21468

11. Hoyos P, Pace V, Alcántara AR (2019) Biocatalyzed synthesis of statins: a sustainable strategy for the preparation of valuable drugs. Catalysts 9:260. https://doi.org/10.3390/catal9030260

12. Handelsman J, Rondon MR, Brady SF, Clardy J, Goodman RM (1998) Molecular biological access to the chemistry of unknown soil microbes: a new frontier for natural products. Chem Biol 5(10):R245-R249. https://doi. org/10.1016/s1074-5521(98)90108-9

13. Taberlet P, Coissac E, Hajibabaei M, Rieseberg LH (2012) Environmental DNA. Mol Ecol 21(8):1789-1793. https://doi.org/10.1111/j.1365-294X. 2012.05542x

14. Gupta V, Singh I, Kumar P, Rasool S, Verma V (2019) A hydrolase with esterase activity expressed from a fosmid gene bank prepared from DNA of a North West Himalayan glacier frozen soil sample. 3 Biotech 9(3):107. https://doi.org/10.1007/s13205-019-1621-z

15. Pandit AS, Joshi MN, Bhargava P, Ayachit GN, Shaikh IM, Saiyed ZM, Saxena AK, Bagatharia SB (2014) Metagenomes from the saline desert of kutch. Genome Announc 2(3):e00439-e514. https://doi.org/10.1128/ genomeA.00439-14

16. Kadnikov W, Savvichev AS, Mardanov AV, Beletsky AV, Chupakov AV, Kokryatskaya NM, Pimenov NV, Ravin NV (2020) Metabolic diversity and evolutionary history of the archaeal phylum "Candidatus micrachaeota" 
uncovered from a freshwater lake Metagenome. Appl Environ Microbiol 86(23):e02199-e2220. https://doi.org/10.1128/AEM.02199-20

17. Kumaresan D, Stephenson J, Doxey AC, Bandukwala H, Brooks E, Hillebrand-Voiculescu A, Whiteley AS, Murrell JC (2018) Aerobic proteobacterial methylotrophs in Movile Cave: genomic and metagenomic analyses. Microbiome 6(1):1. https://doi.org/10.1186/s40168-017-0383-2

18. Kim HJ, Jeong YS, Jung WK, Kim SK, Lee HW, Kahng HY, Kim J, Kim H (2015) Characterization of novel family IV esterase and family I.3 lipase from an oil-polluted mud flat metagenome. Mol Biotechnol 57(9):781792. https://doi.org/10.1007/s12033-015-9871-4

19. Kim YH, Kwon EJ, Kim SK, Jeong YS, Kim J, Yun HD, Kim H (2010) Molecular cloning and characterization of a novel family VIII alkaline esterase from a compost metagenomic library. Biochem Biophys Res Commun 393(1):45-49. https://doi.org/10.1016/j.bbrc.2010.01.070

20. Jensen MS, Fredriksen L, MacKenzie AK, Pope PB, Leiros I, Chylenski P, Williamson AK, Christopeit T, Østby H, Vaaje-Kolstad G, Eijsink V (2018) Discovery and characterization of a thermostable two-domain GH6 endoglucanase from a compost metagenome. PLoS ONE 13(5):e0197862. https://doi.org/10.1371/journal.pone.0197862

21. Ellilä S, Bromann P, Nyyssönen M, Itävaara M, Koivula A, Paulin L, Kruus K (2019) Cloning of novel bacterial xylanases from lignocellulose-enriched compost metagenomic libraries. AMB Express 9(1):124. https://doi.org/10. 1186/s13568-019-0847-9

22. Lu M, Daniel R (2021) A novel carboxylesterase derived from a compost metagenome exhibiting high stability and activity towards high salinity. Genes 12(1):122. https://doi.org/10.3390/genes12010122

23. Lee HW, Jung WK, Kim YH, Ryu BH, Kim TD, Kim J, Kim H (2016) Characterization of a novel alkaline family VIII esterase with S-enantiomer preference from a compost metagenomic library. J Microbiol Biotechnol 26(2):315-325. https://doi.org/10.4014/jmb.1509.09081

24. Park JE, Jeong GS, Lee HW, Kim H (2021) Molecular characterization of novel family IV and VIII esterases from a compost metagenomic library. Microorganisms 9(8):1614. https://doi.org/10.3390/microorganisms9 081614

25. Park JM, Kang CH, Won SM, Oh KH, Yoon JH (2020) Characterization of a novel moderately thermophilic solvent-tolerant esterase isolated from a compost metagenome library. Front Microbiol 10:3069. https://doi.org/ 10.3389/fmicb.2019.03069

26. Kumar S, Stecher G, Li M, Knyaz C, Tamura K (2018) MEGA X: Molecular evolutionary genetics analysis across computing platforms. Mol Biol Evol 35(6):1547-1549. https://doi.org/10.1093/molbev/msy096

27. Laemmli UK (1970) Cleavage of structural proteins during the assembly of the head of bacteriophage T4. Nature 227(5259):680-685. https://doi. org/10.1038/227680a0

28. Bradford MM (1976) A rapid and sensitive method for the quantitation of microgram quantities of protein utilizing the principle of protein-dye binding. Anal Biochem 72:248-254. https://doi.org/10.1006/abio.1976. 9999

29. Lee JP, Kang MG, Lee JY, Oh JM, Baek SC, Leem HH, Park D, Cho ML, Kim $\mathrm{H}$ (2019) Potent inhibition of acetylcholinesterase by sargachromanol I from Sargassum siliquastrum and by selected natural compounds. Bioorg Chem 89:103043. https://doi.org/10.1016/j.bioorg.2019.103043

30. Ngo TD, Ryu BH, Ju H, Jang EJ, Kim KK, Kim TD (2014) Crystallographic analysis and biochemical applications of a novel penicillin-binding protein/ $\beta$-lactamase homologue from a metagenomic library. Acta Crystallogr D Biol Crystallogr 70(Pt 9):2455-2466. https://doi.org/10.1107/ S1399004714015272

31. Akbulut N, Tuzlakoğlu Öztürk M, Pijning T, Isşever Öztürk S, Gümüşel F (2013) Improved activity and thermostability of Bacillus pumilus lipase by directed evolution. J Biotechnol 164(1):123-129. https://doi.org/10. 1016/j.jbiotec.2012.12.016

32. van Pouderoyen G, Eggert T, Jaeger KE, Dijkstra BW (2001) The crystal structure of Bacillus subtilis lipase: a minimal alpha/beta hydrolase fold enzyme. J Mol Biol 309(1):215-226. https://doi.org/10.1006/jmbi.2001. 4659

33. Simons JW, van Kampen MD, Ubarretxena-Belandia I, Cox RC, Alves dos Santos CM, Egmond MR, Verheij HM (1999) Identification of a calcium binding site in Staphylococcus hyicus lipase: generation of calcium-independent variants. Biochem 38(1):2-10. https://doi.org/10.1021/bi981869|

34. Wi AR, Jeon SJ, Kim S, Park HJ, Kim D, Han SJ, Yim JH, Kim HW (2014) Characterization and a point mutational approach of a psychrophilic lipase from an arctic bacterium, Bacillus pumilus. Biotechnol Lett 36(6):12951302. https://doi.org/10.1007/s10529-014-1475-8

35. Zheng X, Guo J, Xu L, Li H, Zhang D, Zhang K, Sun F, Wen T, Liu S, Pang H (2011) Crystal structure of a novel esterase Rv0045c from Mycobacterium tuberculosis. PLoS ONE 6(5):e20506. https://doi.org/10.1371/journal.pone. 0020506

36. Guo J, Zheng X, Xu L, Liu Z, Xu K, Li S, Wen T, Liu S, Pang H (2010) Characterization of a novel esterase Rv0045c from Mycobacterium tuberculosis. PLoS ONE 5(10):e13143. https://doi.org/10.1371/journal.pone.0013143

37. Rashamuse K, Ronneburg T, Hennessy F, Visser D, van Heerden E, Piater L, Litthauer D, Möller C, Brady D (2009) Discovery of a novel carboxylesterase through functional screening of a pre-enriched environmental library. J Appl Microbiol 106(5):1532-1539. https://doi.org/10.1111/j.1365-2672. 2008.04114.x

38. De Simone G, Menchise V, Manco G, Mandrich L, Sorrentino N, Lang D, Rossi M, Pedone C (2001) The crystal structure of a hyper-thermophilic carboxylesterase from the archaeon Archaeoglobus fulgidus. J Mol Biol 314(3):507-518. https://doi.org/10.1006/jmbi.2001.5152

39. Manco G, Giosuè E, D'Auria S, Herman P, Carrea G, Rossi M (2000) Cloning, overexpression, and properties of a new thermophilic and thermostable esterase with sequence similarity to hormone-sensitive lipase subfamily from the archaeon Archaeoglobus fulgidus. Arch Biochem biophys 373(1):182-192. https://doi.org/10.1006/abbi.1999.1497

40. Benavente R, Esteban-Torres M, Acebrón I, de Las RB, Muñoz R, Alvarez Y, Mancheño JM (2013) Structure, biochemical characterization and analysis of the pleomorphism of carboxylesterase Cest-2923 from Lactobacillus plantarum WCFS1. FEBS J 280(24):6658-6671. https://doi.org/10.1111/ febs. 12569

41. De Simone G, Galdiero S, Manco G, Lang D, Rossi M, Pedone C (2000) A snapshot of a transition state analogue of a novel thermophilic esterase belonging to the subfamily of mammalian hormone-sensitive lipase. J Mol Biol 303(5):761-771. https://doi.org/10.1006/jmbi.2000.4195

42. Won SJ, Jeong HB, Kim HK (2020) Characterization of novel salt-tolerant esterase Isolated from the marine bacterium Alteromonas sp. 39-G1. J Microbiol Biotechnol 30(2):216-225. https://doi.org/10.4014/jmb.1907. 07057

43. Park JE, Jeong GS, Lee HW, Kim SK, Kim J, Kim H (2021) Characterization of a novel family IV esterase containing a predicted $\mathrm{CzCO}$ domain and a family $V$ esterase with broad substrate specificity from an oil-polluted mud flat metagenomic library. Appl Sci 11:5905. https://doi.org/10.3390/ app11135905

44. Wei Y, Contreras JA, Sheffield P, Osterlund T, Derewenda U, Kneusel RE, Matern U, Holm C, Derewenda ZS (1999) Crystal structure of brefeldin A esterase, a bacterial homolog of the mammalian hormone-sensitive lipase. Nat Struct Biol 6(4):340-345. https://doi.org/10.1038/7576

45. Ngo TD, Ryu BH, Ju H, Jang E, Park K, Kim KK, Kim TD (2013) Structural and functional analyses of a bacterial homologue of hormone-sensitive lipase from a metagenomic library. Acta Crystallogr D Biol Crystallogr 69(Pt 9):1726-1737. https://doi.org/10.1107/S0907444913013425

46. Sánchez-Carbente M, Batista-García RA, Sánchez-Reyes A, Escudero-Garcia A, Morales-Herrera C, Cuervo-Soto LI, French-Pacheco L, FernándezSilva A, Amero C, Castillo E, Folch-Mallol JL (2017) The first description of a hormone-sensitive lipase from a basidiomycete: Structural insights and biochemical characterization revealed Bjerkandera adusta BaEstB as a novel esterase. Microbiologyopen 6(4):e00463. https://doi.org/10.1002/ mbo3.463

47. Nam KH, Kim MY, Kim SJ, Priyadarshi A, Lee WH, Hwang KY (2009) Structural and functional analysis of a novel EstE5 belonging to the subfamily of hormone-sensitive lipase. Biochem Biophys Res Commun 379(2):553556. https://doi.org/10.1016/j.bbrc.2008.12.085

48. Li PY, Zhang Y, Xie BB, Zhang YQ, Hao J, Wang Y, Wang P, Li CY, Qin QL, Zhang XY, Su HN, Shi M, Zhang YZ, Chen XL (2017) Structural and mechanistic insights into the improvement of the halotolerance of a marine microbial esterase by increasing intra- and interdomain hydrophobic interactions. Appl Environ Microbiol 83(18):e01286-e1317. https://doi. org/10.1128/AEM.01286-17

49. Li PY, Chen XL, Ji P, Li CY, Wang P, Zhang Y, Xie BB, Qin QL, Su HN, Zhou BC, Zhang YZ, Zhang XY (2015) Interdomain hydrophobic interactions modulate the thermostability of microbial esterases from the hormonesensitive lipase family. J Biol Chem 290(17):11188-11198. https://doi.org/ 10.1074/jbc.M1 15.646182 
50. Virk AP, Sharma P, Capalash N (2011) A new esterase, belonging to hormone-sensitive lipase family, cloned from Rheinheimera sp. isolated from industrial effluent. J Microbiol Biotechnol 21(7):667-674. https://doi. org/10.4014/jmb.1103.03008

51. Huo YY, Rong Z, Jian SL, Xu CD, Li J, Xu XW (2017) A novel halotolerant thermoalkaliphilic esterase from marine bacterium Erythrobacter seohaensis SW-135. Front Microbiol 8:2315. https://doi.org/10.3389/fmicb.2017. 02315

52. Hasona A, York SW, Yomano LP, Ingram LO, Shanmugam KT (2002) Decreasing the level of ethyl acetate in ethanolic fermentation broths of Escherichia coli KO11 by expression of Pseudomonas putida estZ esterase. Appl Environ Microbiol 68(6):2651-2659. https://doi.org/10.1128/AEM. 68.6.2651-2659.2002

53. Palm GJ, Fernández-Álvaro E, Bogdanović X, Bartsch S, Sczodrok J, Singh RK, Böttcher D, Atomi H, Bornscheuer UT, Hinrichs W (2011) The crystal structure of an esterase from the hyperthermophilic microorganism Pyrobaculum calidifontis VA1 explains its enantioselectivity. Appl Microbiol Biotechnol 91(4):1061-1072. https://doi.org/10.1007/s00253-011-3337-9

54. Hotta Y, Ezaki S, Atomi H, Imanaka T (2002) Extremely stable and versatile carboxylesterase from a hyperthermophilic archaeon. Appl Environ Microbiol 68(8):3925-3931. https://doi.org/10.1128/AEM.68.8.3925-3931. 2002

55. Huang J, Huo YY, Ji R, Kuang S, Ji C, Xu XW, Li J (2016) Structural insights of a hormone sensitive lipase homologue Est22. Sci Rep 6:28550. https:// doi.org/10.1038/srep28550

56. Canaan S, Maurin D, Chahinian H, Pouilly B, Durousseau C, Frassinetti F, Scappuccini-Calvo L, Cambillau C, Bourne Y (2004) Expression and characterization of the protein Rv1399c from Mycobacterium tuberculosis. A novel carboxyl esterase structurally related to the HSL family. Eur J Biochem 271(19):3953-3961. https://doi.org/10.1111/j.1432-1033.2004. 04335.x

57. Fang Y, Wang S, Liu S, Jiao Y (2015) Discovery a novel organic solvent tolerant esterase from Salinispora arenicola CNP193 through genome mining. Int J Biol Macromol 80:334-340. https://doi.org/10.1016/j.ijbio mac.2015.06.045

58. Boyko KM, Kryukova MV, Petrovskaya LE, Nikolaeva AY, Korzhenevsky DA, Novototskaya-Vlasova KA, Rivkina EM, Dolgikh DA, Kirpichnikov MP, Popov VO (2020) Crystal structure of PMGL2 esterase from the hormonesensitive lipase family with GCSAG motif around the catalytic serine. PLOS ONE 15(1):e0226838. https://doi.org/10.1371/journal.pone.0226838

59. Byun JS, Rhee JK, Kim ND, Yoon J, Kim DU, Koh E, Oh JW, Cho HS (2007) Crystal structure of hyperthermophilic esterase EstE1 and the relationship between its dimerization and thermostability properties. BMC Struct Biol 7:47. https://doi.org/10.1186/1472-6807-7-47

60. Kim BY, Yoo W, Le Huong Luu LT, Kim KK, Kim HW, Lee JH, Kim YO, Kim TD (2019) Characterization and mutation anaylsis of a cold-active bacterial hormone-sensitive lipase from Salinisphaera sp. P7-4. Arch Biochem Biophys 663:132-142. https://doi.org/10.1016/j.abb.2019.01.010

61. Li C, Li Q, Zhang Y, Gong Z, Ren S, Li P, Xie J (2017) Characterization and function of Mycobacterium tuberculosis H37Rv Lipase Rv1076 (LipU). Microbiol Res 196:7-16. https://doi.org/10.1016/j.micres.2016.12.005

62. Bassegoda A, Fillat A, Pastor Fl, Diaz P (2013) Special Rhodococcus sp. CR-53 esterase Est4 contains a GGG(A)X-oxyanion hole conferring activity for the kinetic resolution of tertiary alcohols. Appl Microbiol Biotechnol 97(19):8559-8568. https://doi.org/10.1007/s00253-012-4676-X

63. Maester TC, Pereira MR, Machado Sierra EG, Balan A, de Macedo Lemos EG (2016) Characterization of EST3: a metagenome-derived esterase with suitable properties for biotechnological applications. Appl Microbiol Biotechnol 100(13):5815-5827. https://doi.org/10.1007/s00253-016-7385-z

64. Nam KH, Park SH, Lee WH, Hwang KY (2010) Biochemical and structural analysis of hormone-sensitive lipase homolog Est E7: Insight into the stabilized dimerization of HSL-homolog proteins. Bull Korean Chem Soc 31(9):2627-2632. https://doi.org/10.5012/BKCS.2010.31.9.2627

65. Ki HN, Kim MY, Kim SJ, Priyadarshi A, Kwon ST, Koo BS, Yoon SH, Kwang YH (2009) Structural and functional analysis of a novel hormone-sensitive lipase from a metagenome library. Proteins 74(4):1036-1040. https://doi. org/10.1002/prot.22313

66. Angkawidjaja C, Koga Y, Takano K, Kanaya S (2012) Structure and stability of a thermostable carboxylesterase from the thermoacidophilic archaeon Sulfolobus tokodaii. FEBS J 279(17):3071-3084. https://doi.org/10.1111/j. 1742-4658.2012.08687.x
67. Sumby KM, Matthews AH, Grbin PR, JiranekV (2009) Cloning and characterization of an intracellular esterase from the wine-associated lactic acid bacterium Oenococcus oeni. Appl Environ Microbiol 75(21):6729-6735. https://doi.org/10.1128/AEM.01563-09

68. Jeon JH, Lee HS, Kim JT, Kim SJ, Choi SH, Kang SG, Lee JH (2012) Identification of a new subfamily of salt-tolerant esterases from a metagenomic library of tidal flat sediment. Appl Microbiol Biotechnol 93(2):623-631. https://doi.org/10.1007/s00253-011-3433-x

69. Gricajeva A, Bikutè I, Kalèdienè L (2019) Atypical organic-solvent tolerant bacterial hormone sensitive lipase-like homologue EstAG1 from Staphylococcus saprophyticus AG1: synthesis and characterization. Int J Biol Macromol 130:253-265. https://doi.org/10.1016/j.ijbiomac.2019.02.110

70. Huo YY, Jian SL, Cheng H, Rong Z, Cui HL, Xu XW (2018) Two novel deepsea sediment metagenome-derived esterases: residue 199 is the determinant of substrate specificity and preference. Microb Cell Fact 17(1):16. https://doi.org/10.1186/s12934-018-0864-4

71. Reetz MT (2001) Combinatorial and evolution-based methods in the creation of enantioselective catalysts. Angew Chem Int Ed Engl 40(2):284-310

72. Gupta R, Gupta N, Rathi P (2004) Bacterial lipases: an overview of production, purification and biochemical properties. Appl Microbiol Biotechnol 64(6):763-781. https://doi.org/10.1007/s00253-004-1568-8

\section{Publisher's Note}

Springer Nature remains neutral with regard to jurisdictional claims in published maps and institutional affiliations.

\section{Submit your manuscript to a SpringerOpen ${ }^{\circ}$ journal and benefit from:}

- Convenient online submission

- Rigorous peer review

- Open access: articles freely available online

- High visibility within the field

- Retaining the copyright to your article

Submit your next manuscript at $\boldsymbol{\nabla}$ springeropen.com 